\title{
Structure of Integrated Reporting, Voluntary Disclosure and Firm-Specific Characteristics in Saudi Arabian Companies
}

\author{
Mohammad Hariri ${ }^{1}$ \\ ${ }^{1}$ College of Business Administration, Umm Al-Qura University, Makkah, Saudi Arabia \\ Correspondence: Mohammad M Hariri, College of Business Administration, Umm Al-Qura University, Saudi \\ Arabia. E-mail: mmharriri@uqu.edu.sa
}

Received: July 2, 2021

Accepted: August 25, 2021

Online Published: September 2, 2021

doi:10.5539/ijbm.v16n10p73

URL: https://doi.org/10.5539/ijbm.v16n10p73

\begin{abstract}
The present study aims towards three research purposes. Firstly, it intends to reveal the pattern that associates the elements of the Integrated Reporting (IR) of companies listed on the Saudi Arabian Stock Exchange (Tadawul). Secondly, it verifies the existence of a relationship between IR practices and some firm-specific characteristics. Third, it examines the similarities between the IR practices of these companies. IR communicates how an organization's strategy, governance, performance, and prospects lead to value creation. The dataset used for the IR elements is retrieved from Tadawul and consists of data regarding integrated reports for 126 companies listed in 2019; while the data for the firm-specific characteristics, as the size of the company, the auditor type and the type of company are extracted from Marketscreener.com and Argaam.com portals. The methodology used consists of the empirical-analytical approach with the use of Optimal Scaling techniques. Main findings consist of a positive association found between the elements of the IR, as well as that the specific characteristics of the firms are not related to the elements of the IR. In our results a dissimilarity is found in the corporate information disclosure practices. These findings reveal a need for a deep investigation of the IR elements and firm characteristics in Saudi Arabian companies. One of the future research direction is a multilinear data for various years such that can reveal a more comprehensive understanding of IR elements and firm characteristics. This study becomes relevant in the context of IR elements and firm characteristics relations, that are not yet studies at their research potential.
\end{abstract}

Keywords: accounting, integrated report, corporate report, voluntary disclosure, firm-specific characteristics, Saudi Arabia.

\section{Introduction}

The global economy is continually changing as companies face global competition, technological innovations, and increased regulation in response to financial and governance crises (Flower, 2015). Meanwhile, culture and society question the underlying justification for the nature of a business organization as emphasis on business is limited and ignores the creation of value or justice for people, society and the world (Dumay et al., 2016).

Due to this challenge, in recent years there has been a growing demand from stakeholders for companies to adopt policies related to environmental, social and governance (ESG) issues (McWilliams \& Siegel, 2000; Flower, 2015) and for these topics to be incorporated into corporate reports (Adams \& Frost, 2008; White, 2005). This pressure has forced companies to change their business practices to a more value creation perspective (Velte \& Stawinoga, 2017; Kolk \& van Tulder, 2010).

Therefore, companies need to provide voluntary disclosure of information related to their sustainability (Fasan, 2013). A variety of organizations have emerged, such as the International Integrated Reporting Council (IIRC), to strengthen and expand the quality of corporate information (Busco et al., 2013). Regulatory offices and international standard setters have issued comprehensive regulations related to these subjects (Briano et al., 2012; Ahmed, 2013; Flower, 2015; Velte \& Stawinoga, 2017), with the result being the Integrated Reporting (IR) concept.

The emergence of integrated information has opened up new research perspectives for corporate reporting, as it appears to address the limitations of traditional reporting practices and improves the quality of corporate information that is disclosed to different stakeholders. Solomon and Maruno (2012) examined the impact of the 
mandatory introduction of integrated reports on ESG issues, showing a significant increase in the amount of information reported by the companies in the sample.

Among Saudi companies, the investigation of the purpose of CSR practices during the period 2010 to 2012 found that, despite the low level of disclosure regarding the investigated topics, there was a significant increase in CSR practices (Aldosari \& Atkins, 2015). In recent years, however, few such academic studies have been conducted in Arab nations. This means that the level of CSR (and therefore the level and determinants of IR practices among companies listed on the Saudi stock exchange) have yet to be reflected in the academic literature. The present study seeks to resolve this gap.

The aim of this study is to reveal the connects the elements of corporate reports from companies listed on the Saudi Arabian Stock Exchange (Tadawul). Similarly, it is proposed to test the existence of a relationship between corporate information disclosure practices and some specific firm characteristics, such as the company's size and profitability, the type of auditor, and the type of industry. Finally, the purpose of this study is to compare the disclosure practices of these companies.

\section{Literature Review}

\subsection{The Kingdom of Saudi Arabia as the Context of the Investigation}

The Kingdom of Saudi Arabia (KSA) is the largest economy in the Middle East and North Africa (MENA) region, with a per capita Gross Domestic Product (GDP per capita) of US \$ 21,561.70 and growth of GDP of 1.2\% at the end of 2019 (World Bank, 2019), being an oil-producing country, as $90 \%$ of its total income comes from oil production and export.

The Saudi Arabian Stock Market (Tadawul) was established in 1930 with 14 companies listed on it in 1975 . The number increased over time, reaching 169 companies at the end of 2014, and 199 companies at the end 2019 (Tadawul, 2020).

In 2005, KSA Government established the Saudi Arabia Responsible Competitiveness Index (SARCI) and placed it under the administration of the Saudi General Investment Authority (SAGIA). Later, in 2006, the Capital Market Authority (CMA) issued the Corporate Governance Code, which recommends that all companies that appear on its list of affiliates disclose information about their governance to the public. These initiatives suggest that the nation's authorities have been taking active steps toward adopting voluntary disclosure practices on corporate governance and corporate social responsibility.

While IR and CSR practices are in a new stage in the world, in KSA they have become part of the business practices (Velte \& Stawinoga, 2017; Haller \& van Staden, 2014). This may be the effect of adopting SARCI, as this index assesses the degree to which companies apply and informs CSR practices.

The Saudi Arabian CSR Code, which is a recommendation that all Tadawul-listed companies report their CSR and IR practices, is also in effect proof that the Saudi authorities are ahead of this issue and are taking measures to promote IR practices in the country (Marx \& Mohammadali-Haji, 2014).

\subsection{Integrated Reporting}

The IR could take over the traditional reporting system for the foreseeable future (Jones \& Slack, 2012; Adams \& Frost, 2008) as it is improving the way organizations think, plan, and report their business history (IIRC, 2013).

Due to their novelty, integrated reports (IR) have become an issue of interest to scholars. Some studies have investigated the scope of voluntary corporate information disclosure practices and the factors that influence the company's decision to participate in such practices (KPMG, 2012). Other research has focused on evaluating the position and objectives of the IR (Dumay et al., 2016; Stacchezzini, Melloni \& Lai, 2016), the key issues of the IR system (Haller \& van Staden, 2014; Higgins, Stubbs \& Love, 2014) and the relationship between IR and CSR (Adams et al, 2016; Maas et al, 2016; Sierra García et al., 2015). On the other hand, there is a lack of literature on the of IR quality assessment (Marx \& Mohammadali-Haji, 2014; Ruiz - Lozano \& Tirado - Valencia, 2016).

The literature has recently highlighted the determinants of IR, focusing on why companies generate integrated reports and what are the explanatory factors for their adoption (Frías-Aceituno, Rodríguez-Ariza \& García-Sánchez, 2013; Jensen \& Berg, 2012; Rezaee, 2016). Other authors, through case study research, have explored key issues in IR implementation (Burke \& Clark, 2016; Havlová, 2015; Mio, 2016), and some scholars have identified open questions in the adoption process of IR (Villiers et al., 2014; Villiers \& Sharma, 2017; Flower, 2015; Rezaee, 2016).

Integrated Reporting (IR) is a process that results in communicating value creation over time. IR provides 
concise and independent communication on how an organization's strategy, governance, performance, and prospects lead to short, medium, and long-term value creation (Busco et al., 2013). The key objective of IR is to improve accountability and management based on six kinds of capital, or "capitals" (financial, manufactured, intellectual, human, social and relational, and natural). In doing this, the goal of IR is to support integrated thinking, decision-making and actions that are focused on creating sustainable value for stakeholders.

According to IIRC (2013), IR must be made up of Fundamental Principles, Concepts and Elements. These principles are strategic approach and future orientation, as IR should provide information on the organization's strategy; information connectivity, since the IR report should be displayed as a comprehensive story of value creation; stakeholder response capacity, as IR should provide information on the quality of the organization's relationships with its key stakeholders; materiality and conciseness, since IR should provide concise information that serves as material to assess the organization's ability to create value; reliability and integrity, as IR should include all material issues, both positive and negative; and coherence and comparability as the information should be presented on a basis that is consistent over time and in a manner that allows comparison with other organizations.

Fundamental concepts of IR are represented by (1) the six capitals that an organization uses and affects; (2) the organization's business model; and (3) the creation of value over time (Busco et al, 2013).

The elements of IR, as stated by IIRC (2013), are divided into 45 items distributed among the 6 elements: organizational overview and outlook (6 items); governance (6 items); business model (7 items); risk and opportunities (12 items); strategy and resource allocation ( 7 items); and performance (7 items).

\subsection{Firm-Specific Characteristics and Their Relationship with the Voluntary Disclosure of Corporate Information}

The corporate reporting literature indicates that, in some recognizable respects, many firm-specific characteristics influence the extent of disclosure (e.g., Cerf, 1961; Hossain et al, 1994; Al-Bastaki, 1997; Vitolla et al, 2020). Similarly, research on CSR practices has identified several variables for the chosen companies that could affect the scope of such practices (for example, Hanafi, 2006). These variables include company size, profitability, type of industry, and type of auditor.

Various theories contend that profitable companies should be able to communicate with the public by participating in voluntary reports in order to distinguish themselves from other low-performing companies (Larrán \& Giner, 2002; Marston \& Polei, 2004; Bokpin, 2013). Management of high-performing organizations is frequently encouraged to provide more voluntary details in order to help their organization's continuity and revenue. Larrán \& Giner, 2002; Oyelere et al., 2003; Bokpin, 2013). Cormier et al (2005) argue that higher levels of CSR are required from successful companies, since they can afford to finance such activities. The evidence on profitability is mixed. Ashbaugh et al. (1999) found a positive relationship, while others (Larrán \& Giner, 2002; Marston, 2003; Oyelere et al., 2003; Marston and Polei, 2004; Cormier et al., 2005; Kelton and Yang, 2008) did not find a statistically significant relationship.

The link between company size and the degree of corporate disclosure has been thoroughly investigated, and almost all current literature on corporate disclosure incorporates this factor in its studies (Bonson \& Escobar, 2006; Kribat et al, 2013; Mawardani \& Harymawan, 2020).

Bigger companies are more visible in the capital market and in society in general, so these companies are under greater pressure to provide more disclosure (Marston \& Polei, 2004; Mawardani \& Harymawan, 2020). There is evidence in many studies of a positive relationship between size and level of disclosure in both developed and developing countries (Salama, 2003; Kribat et al., 2013; Hanafi, 2006; Rebman, 2020).

The agency theory holds that auditing helps minimize conflicts of interest between managers and investors. (Xiao et al., 2004; Mawardani \& Harymawan, 2020; Ghani et al., 2018). In general, larger audit firms have a stronger incentive to maintain their independence and impose stricter and more extensive disclosure standards because auditors have more to lose from reputational damage (Bonson \& Escobar, 2006; Mawardani \& Harymawan, 2020). Compared to smaller auditors, large audit firms, especially international ones (called Big-4 in this study) can facilitate the spread of innovative practices, and their reputations can provide some protection against uncertainty and better control over the visibility through the Internet. Xiao et al. (2004) and Samaha and Dahawy (2011) found a positive relationship between them, while Kelton and Yang (2008) and Mawardani and Harymawan (2020) did not find any significant association.

The degree of corporate information disclosure can be influenced by the industry type. Companies in the same industry attempt to follow similar disclosure practices, and if a company within a given industry fails to comply 
with disclosure rules, it can send a negative signal to the market (Craven \& Marston, 1999; Raimo et al., 2020). According to Oyelere et al. (2003), companies operating in more prominent sectors can use IR to mitigate potential political costs. According to Clarkson et al. (2011), most polluting industries are more likely to participate in CSR activities due to their obvious negative impact on the environment.

\section{Methodology}

\subsection{Research Approach and Design}

This research is conducted under the empirical-analytical approach, in which a set of hypotheses is tested to identify the degree of association between the elements of the Integrated Reporting, and between these elements and the firm-specific characteristics in the context of the KSA. In addition, the extent and patterns of voluntary disclosure of corporate information are studied. A cross-sectional design was used since the information collected on the issues occurs at a single point in time, which is the end of the year 2019.

\subsection{Population and Sample}

For the purposes of this study, all non-financial sector companies listed in Tadawul in 2019 are considered. Annual corporate reports of the companies were downloaded from the Tadawul website and / or companies' websites. Financial sector companies were excluded from the study because they are subject to different types of regulations and standards. In total, 126 companies are scrutinized, of which 15 are excluded as they did not disclose their corporate reports, and 19 as they present outliers in some elements of the corporate report. Therefore, the final sample was made up of 92 companies that are part of 15 industrial sectors.

\subsection{Measurement of Key Constructs}

The measurements used are the elements of the IR and the firm-specific characteristics. According to the structure proposed by the IIRC (2013), the IR is made up of 45 items, distributed among 6 elements. The measurement carried out consisted of checking, for the companies surveyed, whether or not each item is disclosed in their corporate report. The measurement is recorded on a dichotomous scale whose categories have the following meanings: $1=$ NOT DISCLOSED, 2 = DISCLOSED.

The firm characteristics that are addressed in this investigation come from secondary sources extracted from the Marketscreener.com and Argaam.com portals. The profitability measure used is Return of Assets (ROA), which assesses the benefit obtained by investing in assets. The size of the company is calculated according to the criteria of Bonson and Escobar (2006), based on its market capitalization at the end of 2019.

The type of auditor is measured by a dichotomous variable whose categories ( 2 and 1$)$ indicate, respectively, if the company is audited by any of the 4 main auditing firms of KSA or by a company other than them. Finally, the measure of the type of company is also a dichotomous variable in which categories ( 2 and 1$)$ respectively represent whether or not the companies belong to polluting industrial sectors.

\subsection{Research Hypotheses}

First, the association between the elements of the IR is evaluated. By their own definition, the elements of the corporate report must have a strong association with each other, since otherwise the report would be a group of disconnected chapters that would reflect a chaotic organization, lacking direction and strategic orientation. Hypothesis 1 is formulated as follows:

$\mathrm{H} 1$ : There is a strong association between the elements of the IR.

Second, as indicated above, there is no consensus in the literature on the relationship between some firm-specific characteristics and the voluntary disclosure of corporate information. To provide empirical evidence on these issues, the second hypothesis is formulated as follows:

$\mathrm{H} 2$ : There is a strong association between the elements of the IR and the Specific Characteristics of the Firm.

The third hypothesis seeks to discover whether corporate information disclosure practices among companies listed on Tadawul are similar. It is expected that, as companies that participate in a stock exchange, the information they disclose will have a high incidence of compliance with the guidelines of the Integrated Report proposed by the IIRC (2013), since publishing their information under these standards is a favourable factor to investor confidence and the value of their shares. Therefore, hypothesis 3 is stated as follows:

H3: Voluntary corporate information disclosure practices are similar among Tadawul-listed companies.

\subsection{Data Collection}

Data is obtained from secondary sources. The disclosure of the 45 items that constitute the 6 elements of the 
Integrated Report and the firm-specific characteristics are obtained from the examination of the corporate reports published by the companies on the Tadawul website and their own websites. In addition, the profitability, the size of the company, the auditor type and the type of company are extracted from Marketscreener.com and Argaam.com portals.

With the data collected, a database of the case-variables type was built, made up of 92 rows that represent the companies and 49 columns that represent the items of IR and the firm-specific characteristics.

\subsection{Analysis Techniques}

Optimal scaling statistical techniques are used to analyse the data and test the research hypotheses.

To test hypotheses 1 and 2, the Nonlinear Canonical Correlation Analysis (OVERALS) is used, after a data reduction is previously performed using the Categorical Principal Components Analysis (CATPCA) procedure. For example, the 6 elements from "Organizational Overview and Perspective" are reduced by means of a CATPCA analysis to 2 components (A1 and A2). In the results of this analysis, the components loadings are obtained, which in this case are equivalent to the Pearson correlations between the items and components A1 and A2.

These component loadings reveal the contribution of each item in A1 and A2. In the same way, we proceeded with the other 5 elements of the IR; 2 or 3 components were obtained for each one of them, with their corresponding component loadings: Governance (B1 and B2), Business Model (C1 and C2), Risks and Opportunities (D1, D2 and D3), Strategy and Resource Allocation (E1 and E2) and Performance (F1 and F2).

The 13 components obtained, as well as the firm-characteristics, are continuous variables. As one of the requirements of OVERALS is that these variables be categorical, each of them was discretized into 7 categories with normal distribution. The firm-characteristics are divided into Financial Characteristics (Profitability and Size of the Company) and Non-Financial Characteristics (Type of Auditor and Type of Industry).

With the execution of the OVERALS procedure, an optimal solution of 2 independent Dimensions is obtained, with relevant results of Multiple Fit, Single Fit and Component Loadings that allow testing hypotheses 1 and 2 , since they reveal the associations of the sets with the Dimensions of the solution.

The 2 dimensions obtained in OVERALS are made up of scores assigned by the procedure to each company, whose values optimize the associations between sets and dimensions. Therefore, by analysing the distribution of companies in this two-dimensional space, Hypothesis 3 can be tested. To this end, with the 2 dimensions, a K-Media type Cluster Analysis is performed in order to classify the companies into dissimilar groups of similar companies. The test of hypothesis 3 is deduced from the analysis of the composition of the clusters obtained.

The calculations are performed with IBM SPSS v.21 software and MS Excel.

\section{Results}

4.1 Test of Hypothesis 1 (H1)

\section{H1: There is a strong association between the elements of the IR.}

To test this hypothesis, the results of the multiple fit and the single fit presented in Table 1 are analysed. 
Table 1. Multiple fit and single fit of components/variables

\begin{tabular}{|c|c|c|c|c|c|}
\hline \multirow[t]{2}{*}{ Set } & \multirow[t]{2}{*}{ Name } & \multirow[t]{2}{*}{ Component / Variable } & \multirow{2}{*}{$\begin{array}{l}\text { Multiple Fit } \\
\text { Sum }\end{array}$} & \multicolumn{2}{|c|}{$\begin{array}{l}\text { Single Fit } \\
\text { Dimension }\end{array}$} \\
\hline & & & & 1 & 2 \\
\hline \multirow{2}{*}{1} & \multirow{2}{*}{ Organizational Overview and Outlook } & A1 & 1,064 & 855 & , 145 \\
\hline & & A2 &, 686 &, 001 & ,681 \\
\hline \multirow{2}{*}{2} & \multirow[t]{2}{*}{ Governance } & B1 & ,772 &, 637 &, 110 \\
\hline & & B2 & ,380 & ,090 & ,279 \\
\hline \multirow{3}{*}{3} & \multirow[t]{2}{*}{ Business Model } & $\mathrm{C} 1$ & 945 & ,775 & 000 \\
\hline & & $\mathrm{C} 2$ & ,364 &, 022 & ,338 \\
\hline & \multirow[t]{3}{*}{ Risks and Opportunities } & D1 &, 822 & 801 &, 001 \\
\hline \multirow[t]{2}{*}{4} & & D2 & ,293 &, 023 &, 251 \\
\hline & & D3 & ,351 &, 000 & ,347 \\
\hline \multirow{2}{*}{5} & \multirow[t]{2}{*}{ Strategy and Resources Allocation } & E1 & 1,048 & 1,005 &, 009 \\
\hline & & $\mathrm{E} 2$ &, 162 &, 064 &, 092 \\
\hline \multirow{2}{*}{6} & \multirow[t]{2}{*}{ Performance } & $\mathrm{F} 1$ &, 882 & ,781 & 086 \\
\hline & & $\mathrm{F} 2$ &, 566 &, 044 &, 518 \\
\hline \multirow{2}{*}{7} & \multirow[t]{2}{*}{ Financial Characteristics } & ROA & ,347 &, 114 & , 153 \\
\hline & & SIZE & ,365 &, 013 & ,285 \\
\hline \multirow{2}{*}{8} & \multirow[t]{2}{*}{ Non-financial Characteristics } & INDUSTRY & 022 & 021 & 001 \\
\hline & & AUDITOR & ,235 &, 016 & ,219 \\
\hline
\end{tabular}

For each component / variable, the multiple fit represents its discriminant power. High values of the multiple fit mean that a variable discriminates better. Examining the multiple fit in Table 1 shows that components A1, A2, $\mathrm{B} 1, \mathrm{C} 1, \mathrm{D} 1, \mathrm{E} 1, \mathrm{~F} 1$ and $\mathrm{F} 2$ are the ones that discriminate the best.

The single fit serves to break down the discriminant power in the 2 dimensions of the solution. Therefore, it is observed that the components A1, B1, C1, D1, E1 and F1 mainly discriminate in the first dimension, while the components A2 and F2 discriminate almost totally in the second dimension.

It is apparent that all the sets configured with the elements of the IR are strongly associated, since a component of each set has a high discriminating power in Dimension 1, which allows the conclusion that $\mathrm{H} 1 \mathrm{may}$ be accepted.

\subsection{Test of Hypothesis 2 (H2)}

$\mathrm{H} 2$ : There is a strong association between the elements of the Integrated Report and the firm-specific characteristics.

The examination of Table 1 shows that the 4 firm-specific characteristics have very low multiple fit values, therefore they have little importance in the solution obtained. To verify this assertion, a bivariate correlation analysis (Spearman's rho) is performed. This matrix is shown in Table 2.

Table 2. Matrix of bivariate correlations of the characteristics of the firms and the dimensions of OVERALS

\begin{tabular}{|c|c|c|c|c|c|c|c|}
\hline & & ROA & SIZE & INDUSTRY & AUDITOR & Dimension 1 & Dimension 2 \\
\hline \multirow{2}{*}{ ROA } & Correlation coefficient (Spearman's rho) & 1,000 & & & & & \\
\hline & Sig. (bilateral) & & & & & & \\
\hline \multirow{2}{*}{ SIZE } & Correlation coefficient (Spearman's rho) &, $522^{* *}$ & 1,000 & & & & \\
\hline & Sig. (bilateral) &, 000 & & & & & \\
\hline \multirow{2}{*}{ INDUSTRY } & Correlation coefficient (Spearman's rho) &, 059 &, 045 & 1,000 & & & \\
\hline & Sig. (bilateral) &, 574 & ,669 & & & & \\
\hline \multirow{2}{*}{ AUDITOR } & Correlation coefficient (Spearman's rho) & , 125 &,- 020 &,$- 216^{*}$ & 1,000 & & \\
\hline & Sig. (bilateral) &, 237 &, 853 &, 040 & & & \\
\hline \multirow{2}{*}{ Dimension 1} & Correlation coefficient (Spearman's rho) &,- 096 &,- 044 & 085 & ,139 & 1,000 & \\
\hline & Sig. (bilateral) & ,365 & 680 & ,419 &, 189 & & \\
\hline \multirow{2}{*}{ Dimension 2} & Correlation coefficient (Spearman's rho) & 181 &,$- 309^{* *}$ &,- 133 &, $479^{* *}$ &, 121 & 1,000 \\
\hline & Sig. (bilateral) & 083 &, 003 & ,207 &, 000 &, 251 & \\
\hline
\end{tabular}

* Significant at $\mathrm{p}<0,05$.

** Significant at $\mathrm{p}<0,01$.

Source: Author (2021). 
This analysis detects that Dimension 2 has a positive correlation $(\rho=0.479)$ with the type of auditor and a negative correlation $(\rho=-0.309)$ with the size of the company. Both are weak, but significant, as $p<0.01$.

The elements of IR are associated in dimension 1 while the type of auditor and the size of the company correlate with dimension 2. Since these dimensions are independent of each other, the test of hypothesis 2 concludes that $\mathrm{H} 2$ is not acceptable.

\subsection{Test of Hypothesis 3 (H3)}

H3: The practices of voluntary disclosure of corporate information are similar among companies listed on Tadawul.

The OVERALS analysis obtained a 2-Dimensional solution consisting of standardized scores assigned to the companies in each dimension, in such a way as to optimize the associations between the sets and the dimensions.

Therefore, these coordinates can be represented in a two-dimensional space to observe the distribution of companies based on their disclosure practices (dimension 1) and their firm-specific characteristics and sustainability perspectives (dimension 2).

To better observe the distribution of companies in these dimensions, a K-means clusters analysis was performed, which yielded 3 clusters that have the maximum dissimilarity between them, and maximum similarity between the companies that make up the study. These results are represented in Figure 1 and Table 3.

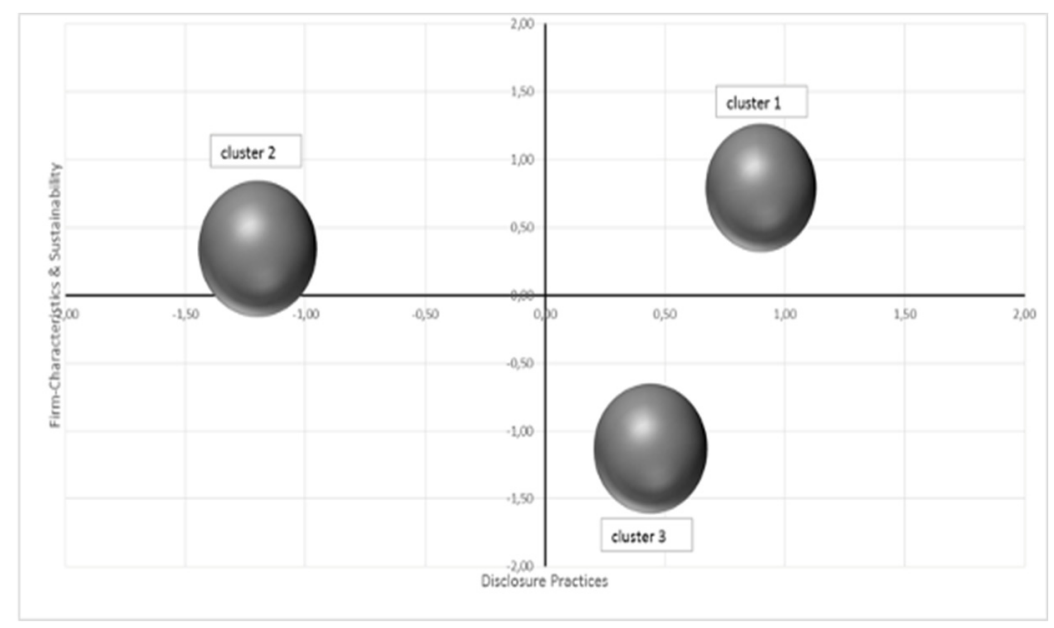

Figure 1. Cluster of companies in OVERALS' dimensions

Table 3. Cluster analysis

\begin{tabular}{lllllll}
\hline \multirow{2}{*}{ Cluster } & Dimension 1 & Dimension 2 & $\mathrm{N}^{\circ}$ of Companies & \multicolumn{5}{c}{ Distance between Centres } \\
& & & & 1 & 2 & 3 \\
\hline 1 & 0,90 & 0,79 & 29 & 0,000 & & \\
2 & $-1,20$ & 0,34 & 33 & 2,148 & 0,000 & \\
3 & 0,44 & $-1,13$ & 30 & 1,974 & 2,202 & 0,000 \\
\hline
\end{tabular}

This analysis shows the companies classified into 3 clusters; whose centres are separated from each other by distances close to 2 standardized units. Cluster 1 is made up of 29 companies that are characterized by extensively practicing the disclosure of their corporate information, at the same time including the concept of sustainability in their perspectives. They are the companies that employ big auditing firms, and their size is slightly above the general average of the companies studied.

Cluster 2 has 33 companies whose main characteristic is that their corporate information disclosure practices are poorly developed, but that takes into account their sustainability in the present and future perspectives. Its size is somewhat higher than the general average for companies.

Finally, cluster 3 includes 30 companies with good practices for disclosing their corporate information but, which do not disclose their strategic orientation towards sustainability. In general, they are companies of a size 
somewhat below the average, audited by firms other than the big and most prestigious. This analysis shows differences in the corporate information disclosure practices among the companies studied; therefore it is concluded that $\mathrm{H} 3$ is not to be accepted.

Table 4 shows the structure found in the OVERALS and CATPCA analyses, as well as the statistics that reveal the association of the items, components and dimensions in the solution; the single fit supports the association of the sets with the dimensions, while component loadings support the association of the items with the components.

Table 4 reveals that all the elements of the IR are associated in Dimension 1 of OVERALS, through components A1, B1, C1, D1, E1 and F1. This dimension is called "Disclosure Practices." On the other hand, in Dimension 2 of OVERALS the size of the company, the type of auditor and 2 components of the IR (A2 and F2) that have to do with sustainability and the present and future perspectives of the company are represented.

This dimension can be called "Firm-Specific Characteristics \& Sustainability". Both dimensions run on a continuum of standardized values in a range from -2 (Low) to 2 (High).

Table 4. Relevant associations in OVERALLS and CATPCA

\begin{tabular}{|c|c|c|c|c|c|c|c|c|}
\hline \multicolumn{5}{|c|}{ OVERALS } & \multicolumn{4}{|c|}{ CATPCA } \\
\hline \multirow{3}{*}{ Set } & \multirow{3}{*}{ Name } & \multirow{3}{*}{ Variable } & \multirow{2}{*}{\multicolumn{2}{|c|}{$\begin{array}{l}\text { Single Fit } \\
\text { Dimension }\end{array}$}} & \multirow{3}{*}{ Item } & \multirow{3}{*}{ Description } & \multirow{2}{*}{\multicolumn{2}{|c|}{$\begin{array}{l}\text { Component } \\
\text { Dimension }\end{array}$}} \\
\hline & & & & & & & & \\
\hline & & & 1 & 2 & & & 1 & 2 \\
\hline \multirow{5}{*}{1} & \multirow{5}{*}{$\begin{array}{l}\text { Organizational } \\
\text { Overview and } \\
\text { Outlook }\end{array}$} & \multirow{4}{*}{ A1 } & \multirow{4}{*}{, 855} & \multirow{8}{*}{,681 } & 2 & Stating ethics and values & 0,791 & \\
\hline & & & & & 4 & $\begin{array}{l}\text { Providing implications for future } \\
\text { financial performance }\end{array}$ & 0,597 & \\
\hline & & & & & 5 & Describing report boundaries $\quad 0$ & 0,659 & \\
\hline & & & & & 6 & $\begin{array}{l}\text { Describing frameworks used to } \\
\text { quantify material aspects }\end{array}$ & 0,606 & \\
\hline & & $\mathrm{A} 2$ & & & 1 & $\begin{array}{l}\text { Integration of sustainability within } \\
\text { Mission/Vision }\end{array}$ & & 0,715 \\
\hline \multirow{3}{*}{2} & \multirow{3}{*}{ Governance } & \multirow{3}{*}{ B1 } & \multirow{3}{*}{,637 } & & 8 & $\begin{array}{l}\text { Actions taken to influence and } \\
\text { monitor strategic direction of the } 0 \\
\text { organization }\end{array}$ & 0,739 & \\
\hline & & & & & 9 & $\begin{array}{l}\text { How the organization's leadership } \\
\text { engage with key stakeholders }\end{array}$ & 0,814 & \\
\hline & & & & & 11 & $\begin{array}{l}\text { Promoting and enabling innovation } \\
\text { by those charged with governance }\end{array}$ & 0,662 & \\
\hline \multirow{4}{*}{3} & \multirow{4}{*}{$\begin{array}{l}\text { Business } \\
\text { Model }\end{array}$} & \multirow{4}{*}{$\mathrm{C} 1$} & \multirow{4}{*}{\multicolumn{2}{|c|}{,775 }} & 13 & Materiality aspects $\quad 0$ & 0,736 & \\
\hline & & & & & 16 & Improving processes & 0,605 & \\
\hline & & & & & 17 & Employee training on sustainability 0 & 0,691 & \\
\hline & & & & & 18 & Managing supplier relationships $\quad 0$ & 0,724 & \\
\hline \multirow{6}{*}{4} & \multirow{6}{*}{$\begin{array}{l}\text { Risks and } \\
\text { Opportunities }\end{array}$} & \multirow{6}{*}{ D1 } & \multirow{6}{*}{\multicolumn{2}{|c|}{, 801}} & 23 & External economic opportunities & 0,655 & \\
\hline & & & & & 25 & $\begin{array}{ll}\text { External } & \text { environmental } \\
\text { opportunities } & \end{array}$ & 0,600 & \\
\hline & & & & & 27 & External social opportunities $\quad 0$ & 0,651 & \\
\hline & & & & & 28 & External legal risks & 0,615 & \\
\hline & & & & & 30 & Assessment of potential risk & 0,706 & \\
\hline & & & & & 31 & Assessment of potential opportunity 0 & 0,719 & \\
\hline \multirow{4}{*}{5} & \multirow{4}{*}{$\begin{array}{l}\text { Strategy and } \\
\text { Resources } \\
\text { Allocation }\end{array}$} & \multirow{4}{*}{ E1 } & \multirow{4}{*}{1,005} & & 34 & $\begin{array}{l}\text { Measures for assessing strategy } 0 \\
\text { implementation }\end{array}$ & 0,673 & \\
\hline & & & & & 35 & $\begin{array}{l}\text { Stakeholders' insights form part of } \\
\text { the organization's strategy }\end{array}$ & 0,762 & \\
\hline & & & & & 37 & $\begin{array}{l}\text { Changes in the business model to } \\
\text { implement the strategies }\end{array}$ & 0,798 & \\
\hline & & & & & 38 & $\begin{array}{l}\text { How the strategies respond to } \\
\text { external risks and opportunities }\end{array}$ & 0,755 & \\
\hline
\end{tabular}




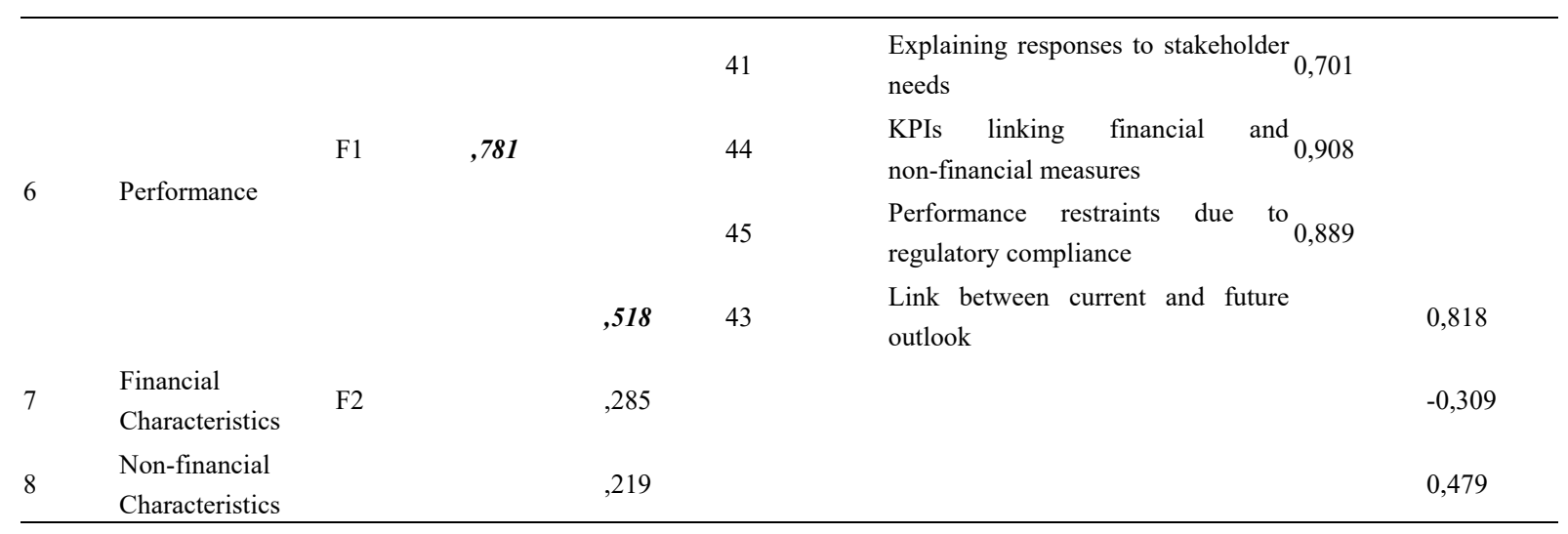

\section{Results}

Concerning the first hypothesis, the findings show that all of the elements of the integrated report are represented by a component with high discriminating power in Dimension 1 of OVERALS. This table also shows that 24 of the 45 initial items make up the structure of these components due to high component loading values. This empirical evidence suggests that there is a strong association between the elements of the IR that companies disclose. This finding supports the studies of Abeysekera (2013), Atkins and Maroun (2015) and Busco et al (2013).

The examination of $\mathrm{H} 2$ reveals that the 4 characteristics of the scrutinized firms have a very low discriminant power in both dimensions. These values show that the firm-specific characteristics are very weakly associated with the dimensions of OVERALS. In the analysis of bivariate correlations, dimension 2 has weak but significant correlations with the type of auditor and the size of the company.

The elements of the IR and two of the firm-specific characteristics are associated with different dimensions; therefore, it is concluded that there is no association between them. These findings support the studies by Cormier et al. (2005), Kelton and Yang (2008), Larrán and Giner (2002), Marston (2003), Marston and Polei (2004) and Oyelere et al. (2003), who did not find any statistically significant relationship between the elements of IR and profitability. In addition, they contradict the states of Hanafi (2006); Kribat et al. (2013); Rebman, (2020) and Salama (2003), who found a positive relationship between these. Third, they contradict the study of Clarkson (2011), who found an association between polluting industries and information disclosure practices related to CSR. Finally, the findings support the studies of Kelton and Yang (2008) and Mawardani and Harymawan (2020), who did not find a significant relationship between the variables.

The third issue addressed in this research is the similarity in the corporate information disclosure practices of companies listed on Tadawul.

As a result of the OVERALS analysis, three clusters of companies were obtained in different quadrants of the two-dimensional space (Figure 1). In cluster 1, there are companies with high standards of corporate information disclosure. Cluster 2 includes companies with limited disclosure practices, and cluster 3 includes the companies with good disclosure practices.

The grouping of companies in heterogeneous clusters, with different disclosure practices and with different extents of consideration for their sustainability, mean a lack of similarity between them. For this reason, it must be concluded that there is difference in extents of corporate information disclosure practices among companies listed on Tadawul.

Regarding the extent of disclosure practices among Saudi companies, Aldosari and Atkins (2015) reported that $81 \%$ (47 of 58) of companies published corporate reports in 2012; they identify a growing trend over time. In this research, $88 \%$ disclosure was achieved (111 out of 126) at the end of 2019. Of the 111 companies that disclosed their corporate report, $92(83 \%)$ presented consistent data, and were included in the analyses performed. Of these 92 companies, it was evidenced that 59 (64\%) (clusters 1 and 3) have high standards of disclosure and integration of their corporative information, in accordance with the IIRC guidelines. $36 \%$ (cluster 2) have limitations in the information disclosed in their reports.

\section{Discussion}

The optimal scaling procedures used in this study allowed us to identify the 24 items of the integrated report that 
are most relevant in the context of Tadawul, as well as how they are related. It is also clear that, in this context, the firm-specific characteristics run in a different dimension than the IR elements, implying that there is no relationship between the two. Of course, given the lack of agreement among scholars on this topic, more empirical evidence is required to clarify this point. Finally, optimal scaling techniques are used to obtain measures that maximize the existing associations between variables.

The research implications of this study are to be considered by regulatory bodies, as the issue of this study provides some important insights on the disclosure of corporate practices; by capital markets structure as well as by companies, as IR tends to become an important issue in the business environment.

In this research, a strong association is evidenced between the elements of IR, thus complying with the principle of information connectivity. Of the 45 items in the integrated report, 24 of them form the structure of its elements, which are strongly associated in the same dimension. On the other hand, the firm-specific characteristics are weakly associated in a different dimension to the elements of IR. For this reason, in our research, it is concluded that IR is not associated with the firm-specific characteristics. Finally, differences are found in corporate information disclosure practices between Saudi Arabian companies. Overall, the present study offers an in-depth analysis of IR practices in KSA and reveals the connections between their elements as well as concluding weak corelations between firm-specific characteristics and the IR practices.

The research implications of the present research rely in the need of a new perspective into the IR studies, alongside with the need for further research into the implications of IR. This paper brings upfront the corellation between the IR elements, the correlation between some firm specific characteristics and the IR elements, as well as it dives into the corporate information disclosure practices between companies that are listed at Tadawul. The implications of this paper are useful for both practitioners as it offers a broad image of the use of IR practices and their correlation to the firm characteristics, as well as to schoolars as it gives a perspective on further research needed in the area of Integrated Reporting and its use in the Saudi Arabian business environment.

This study encompasses the data from 2019 only, therefore more studies are need within this area, especially studies using multilinear data. Beside this, the present study offers a study methodology for the analysis of Saudi Arabia companies in the context of Integrated Reporting, with a focus on the relation between firm characteristics and discosure practices. Therefore, optimal scaling procedures are techniques that should be considered in future research related to IR, as they allow the analysis of all the structures and relationships of the issues of interest. Future studies should also imply working with multiple years as this would allow for a tendency analysis.

\section{References}

Abeysekera, I. (2013). A template for integrated reporting. Journal of Intellectual Capital. https://doi.org/10.1108/14691931311323869

Adams, C. A., \& Frost, G. R. (2008). Integrating sustainability reporting into management practices. Accounting Forum, 32(4), 288-302. https://doi.org/10.1016/j.accfor.2008.05.002

Adams, C. A., Potter, B., Singh, P. J., \& York, J. (2016). Exploring the implications of integrated reporting for social investment (disclosures). The British Accounting Review, 48(3), 283-296. https://doi.org/10.1016/j.bar.2016.05.002

Ahmed, A. H. A. (2013). Corporate Internet Reporting in Egypt: Practices and Perceptions. Ph.D., University of Dundee. Retrieved

from https://discovery.dundee.ac.uk/en/studentTheses/3cd18720-8dcf-4276-9269-6cd6f706f2e6

Al-Bastaki, H. (1997). Extent of disclosure in the annual reports of banks operating in Bahrain. Arab Journal of Administrative Sciences, 5(1), 241-268.

Aldosari, A., \& Atkins, J. (2015). Corporate Social Responsibility in Saudi Arabia. paper presented at the 51st British Accounting and Finance Conference, Manchester, UK.

Ashbaugh, H., Johnstone, K. M., \& Warfield, T. D. (1999). Corporate reporting on the Internet. Accounting Horizons, 3, 241-257.

Atkins, J., \& Maroun, W. (2015). Integrated reporting in South Africa in 2012. Meditari Accountancy Research. https://doi.org/10.1108/medar-07-2014-0047

Bokpin, G. A. (2013). Corporate disclosure, transparency and stock liquidity: Empirical estimation from the Ghana Stock Exchange. African Journal of Business Management, 7(22), 2143-2150. 
Bonson, E., \& Escobar, T. (2006). Digital reporting in Eastern Europe: An empirical study. International Journal of Accounting Information Systems, 7(4), 299-318. https://doi.org/10.1016/j.accinf.2006.09.001

Briano Turrent, G. C., \& Rodríguez Ariza, L. (2012). Corporate information transparency on the Internet by listed companies in Spain (IBEX35) and Mexico (IPYC). Retrieved from https://doi.org/10.4192/1577-8517-v12_1

Burke, J. J., \& Clark, C. E. (2016). The business case for integrated reporting: Insights from leading practitioners, regulators, and academics. Business Horizons, 59(3), 273-283. https://doi.org/10.1016/j.bushor.2016.01.001

Busco, C., Frigo, M. L., Quattrone, P., \& Riccaboni, A. (2013). Towards Integrated Reporting: Concepts, Elements and Principles. In Busco, C., Frigo, M. L., Riccaboni, A., and Quattrone, P. (Eds.), Integrated Reporting: Concepts and Cases That Redefine Corporate Accountability. Springer International Publishing, Cham. https://doi.org/10.1007/978-3-319-02168-3_1

Cerf, A. R. (1961). Corporate reporting and investment decisions. Public Accounting Research Program, Institute of Business and Economic Research, University of California.

Clarkson, P. M., Li, Y., Richardson, G. D., \& Vasvari, F. P. (2011). Does it really pay to be green? Determinants and consequences of proactive environmental strategies. Journal of Accounting and Public Policy, 30(2), 122-144. https://doi.org/10.2139/ssrn.955890

Cormier, D., Magnan, M., \& Velthoven, B. V. (2005). Environmental disclosure quality in large German companies: Economic incentives, public pressures or institutional conditions? European Accounting Review, 14(1), 3-39. https://doi.org/10.1080/0963818042000339617

Craven, B. M., \& Marston, C. L. (1999). Financial reporting on the Internet by leading UK companies. European Accounting Review, 8(2), 321-333. https://doi.org/10.1080/096381899336069

Dumay, J., Bernardi, C., Guthrie, J., \& Demartini, P. (2016). Integrated reporting: A structured literature review. Accounting Forum, 40(3), 166-185. https://doi.org/10.1016/j.accfor.2016.06.001

Fasan, M. (2013). Annual reports, sustainability reports and integrated reports: Trends in corporate disclosure. Integrated reporting, 41-57. https://doi.org/10.1007/978-3-319-02168-3_3

Flower, J. (2015). The International Integrated Reporting Council: A story of failure. Critical Perspectives on Accounting, 27, 1-17. https://doi.org/10.1016/j.cpa.2014.07.002

Frías-Aceituno, J. V., Rodríguez-Ariza, L., \& García-Sánchez, I. M. (2013). Is integrated reporting determined by a country's legal system? An exploratory study. Journal of Cleaner Production, 44, 45-55. https://doi.org/10.1016/j.jclepro.2012.12.006

Ghani, E. K., Jamal, J., Puspitasari, E., \& Gunardi, A. (2018). Factors influencing integrated reporting practices among Malaysian public listed real property companies: a sustainable development effort. International Journal of Managerial and Financial Accounting, 10(2), 144-162. https://doi.org/10.1504/ijmfa.2018.091662

Haller, A., \& Van Staden, C. (2014). The value-added statement - an appropriate instrument for Integrated Reporting. Professor Charl de Villiers, P. J. U. and D. L. R. (Eds.), Accounting, Auditing \& Accountability Journal, 27(7), 1190-1216. https://doi.org/10.1108/aaaj-04-2013-1307

Hanafi, R. A. (2006). An Exploration of Corporate Social and Environmental Disclosure in Egypt and the UK: A Comparative Study. Un-published PhD Thesis, University of Glasgow, Glasgow, UK.

Havlová, K. (2015). What Integrated Reporting Changed: The Case Study of Early Adopters. Procedia Economics and Finance, 34, 231-237. https://doi.org/10.1016/s2212-5671(15)01624-X

Higgins, C., Stubbs, W., \& Love, T. (2014). Walking the talk(s): Organisational narratives of integrated reporting. Accounting, Auditing \& Accountability Journal, 27(7), 1090-1119. https://doi.org/10.1108/aaaj-04-2013-1303

Hossain, M., Tan, L. M., \& Adams, M. (1994). Unitary disclosure in an emerging capital market: Some empirical evidence from companies listed on the Kuala Lumpur Stock Exchange.

IIRC. (2013). The International Integrated Report Framework. Retrieved from http://integratedreporting.org/wp-content/uploads/2013/12/13-12-08-THE-INTERNATIONAL-IR-FRAME WORK-2-1.pdf

Jensen, J. C., \& Berg, N. (2012). Determinants of Traditional Sustainability Reporting Versus Integrated 
Reporting. An Institutionalist Approach. Business Strategy and the Environment, 21(5), 299-316. https://doi.org/10.1002/bse.740

Jones, M., \& Slack, R. E. (2012). The Future of Financial Reporting 2011: Global Crisis and Accounting at Crossroads. Association of Chartered Certified Accountants. Retrieved from http://www.baa.ac.uk/group/assets/files/FAR\%20 SIG/Symposium\%202011.pdf

Kelton, A. S., \& Yang, Y. (2008). The impact of corporate governance on Internet financial reporting. Journal of Accounting and Public Policy, 27(1), 62-87.

Kolk, A., \& Van Tulder, R. (2010). International business, corporate social responsibility and sustainable development. International Business Review, 19(2), 119-125.

KPMG. (2012). Integrated reporting in practice: The South African story. Retrieved from https://www.kpmg.com/Global/en/topics/corporatereporting/betterreporting/Documents/the-south-african-st ory.pdf

Kribat, M., Burton, B., \& Crawford, L. (2013). Evidence on the nature, extent and determinants of disclosures in Libyan banks' annual reports. Journal of Accounting in Emerging Economies, 3(2), 88-114. https://doi.org/10.1108/20421161311288839

Larrán Jorge, M., \& Giner, B. (2002). The use of the internet for corporate reporting by Spanish companies. Retrieved from http://rabida.uhu.es/dspace/handle/10272/1492

Maas, K., Schaltegger, S. and Crutzen, N. (2016). Advancing the integration of corporate sustainability measurement, management and reporting. Journal of Cleaner Production, 133, 859-862. https://doi.org/10.1016/j.jclepro.2016.08.055

Marston, C. (2003). Financial reporting on the Internet by leading Japanese companies. Corporate Communications: An International Journal, 8(1), 23-34. https://doi.org/10.1108/13563280310458894

Marston, C. and Polei, A. (2004). Corporate reporting on the Internet by German companies. International Journal of Accounting Information Systems, 5(3), 285-311. https://doi.org/10.1016/j.accinf.2004.02.009

Marx, B., \& Mohammadali-Haji, A. (2014). Emerging trends in reporting: an analysis of integrated reporting practices by South African top 40 listed companies. Journal of Economic and Financial Sciences, 7(1), 231-250. https://doi.org/10.4102/jef.v7i1.138

Mawardani, H. A., \& Harymawan, I. (2020). The Relationship Between Corporate Governance and Integrated Reporting. Journal of Accounting and Investment, 22(1). https://doi.org/10.18196/jai.v22i1.9694

McWilliams, A., \& Siegel, D. (2000). Corporate social responsibility and financial performance: correlation or misspecification? Strategic Management Journal, 21(5), 603-609. https://doi.org/10.1002/(sici)1097-0266(200005)21:5<603::aid-smj101>3.0.co;2-3

Mio, C. (2016), Integrated Reporting: A New Accounting Disclosure. Springer.

Oyelere, P., Laswad, F., \& Fisher, R. (2003). Determinants of Internet Financial Reporting by New Zealand Companies. Journal of International Financial Management \& Accounting, 14(1), 26-63. https://doi.org/10.1111/1467-646x.00089

Raimo, N., Vitolla, F., Marrone, A., \& Rubino, M. (2021). Do audit committee attributes influence integrated reporting quality? An agency theory viewpoint. Business Strategy and the Environment, 30(1), 522-534. https://doi.org/10.1002/bse.2635

Rebman, R. (2020). Corporate Responsibility, Catholic Social Teaching, and the Common Good: Reporting, Accountability, and Stakeholder Action. Journal of Catholic Social Thought, 18, 99-107. https://doi.org/10.5840/jcathsoc20201718

Rezaee, Z. (2016). Business sustainability research: A theoretical and integrated perspective. Journal of Accounting Literature, 36, 48-64. https://doi.org/10.1016/j.acclit.2016.05.003

Ruiz-Lozano, M., \& Tirado-Valencia, P. (2016). Do industrial companies respond to the guiding principles of the Integrated Reporting framework? A preliminary study on the first companies joined to the initiative. Revista de Contabilidad, 19(2), 252-260. https://doi.org/10.1016/j.rcsar.2016.02.001

Salama, A. (2003). A note on the impact of environmental performance on financial performance. Structural Change and Economic Dynamics, 16(3), 413-421. https://doi.org/10.1016/j.strueco.2004.04.005 
Samaha, K., \& Dahawy, K. (2010). An empirical analysis of corporate governance structures and untary corporate disclosure in atile capital markets: The Egyptian experience. International Journal of Accounting, Auditing and Performance Evaluation, 7(1-2), 61-93. https://doi.org/10.1504/ijaape.2011.037726

Sierra-García, L., Zorio-Grima, A., \& García-Benau, M. A. (2015). Stakeholder Engagement, Corporate Social Responsibility and Integrated Reporting: An Exploratory Study. Corporate Social Responsibility and Environmental Management, 22(5), 286-304. https://doi.org/10.1002/csr.1345

Solomon, J., \& Maroun, W. (2012), Integrated Reporting: The Influence of King III on Social, Ethical and Environmental Reporting, Report, Association of Chartered Certified Accountants. Retrieved from https://research-repository.st-andrews.ac.uk/handle/10023/3749

Stacchezzini, R., Melloni, G., \& Lai, A. (2016). Sustainability management and reporting: the role of integrated reporting for communicating corporate sustainability management. Journal of Cleaner Production, 136, 102-110. https://doi.org/10.1016/j.jclepro.2016.01.109

Tadawul. (2020). $\quad$ eReference Rata. Retrieved from https://www.tadawul.com.sa/wps/portal/tadawul/knowledge-center/about/ereference-data?locale=en

Velte, P., \& Stawinoga, M. (2017). Integrated reporting: The current state of empirical research, limitations and future research implications. Journal of Management Control, 28(3), 275-320. https://doi.org/10.1007/s00187-016-0235-4

Villiers, C. D., Venter, E. R., \& Hsiao, P. C. K. (2017). Integrated reporting: background, measurement issues, approaches and an agenda for future research. Accounting \& Finance, 57(4), 937-959. https://doi.org/10.1111/acfi.12246

Villiers, C., \& Sharma, U. (2020). A critical reflection on the future of financial, intellectual capital, sustainability and integrated reporting. Critical Perspectives on Accounting, 70, 101-999. https://doi.org/10.1016/j.cpa.2017.05.003

Vitolla, F., Raimo, N., Rubino, M., \& Garzoni, A. (2020). The determinants of integrated reporting quality in financial institutions. Corporate Governance: The International Journal of Business in Society, 20(3), 429-444. https://doi.org/10.1108/cg-07-2019-0202

White, A. L. (2005). Fade, Integrate or Transform? The Future of CSR. Retrieved from http://www.jussemper.org/Newsletters/Resources/BSR_Allen-White.pdf

World Bank. (2019). Saudi Arabia: Country Profile. Retrieved from: https://data.worldbank.org/country/SA

Xiao, J. Z., Yang, H., \& Chow, C. W. (2004). The determinants and characteristics of untary Internet-based disclosures by listed Chinese companies. Journal of Accounting and Public Policy, 23(3), 191-225. https://doi.org/10.1016/s0278-4254(04)00021-3

\section{Copyrights}

Copyright for this article is retained by the author(s), with first publication rights granted to the journal.

This is an open-access article distributed under the terms and conditions of the Creative Commons Attribution license (http://creativecommons.org/licenses/by/4.0/). 